\title{
Fixed-Term Jobs after Vocational Education and Training in Switzerland: Stepping Stone or Impediment? ${ }^{1}$
}

\author{
Laura A. Helbling*
}

\begin{abstract}
Competing assumptions about whether entering the labour market via fixed-term jobs is a good or bad start into work life persist in the literature. Based on the longitudinal survey TREE, this article sheds light on (1) who enters the Swiss labour market via fixedterm jobs after graduating from initial vocational education and on (2) the consequences regarding their future returns. Results indicate that vocational education graduates entering the work force via fixed-term jobs of low occupational status must expect lower future wages. Keywords: fixed-term jobs, job insecurity, labour market entry, vocational education and training, wages
\end{abstract}

\section{Befristete Arbeit nach einer beruflichen Grundbildung in der Schweiz: Sprungbrett oder Hindernis?}

Zusammenfassung: In der Literatur stehen sich konkurrierende Annahmen gegenüber, inwiefern befristete Einstiegsstellen einen guten oder schlechten Start ins Erwerbsleben bedeuten. Basierend auf der Längsschnittstudie TREE untersucht dieser Artikel: (1) Wer unter den Absolventen einer beruflichen Grundbildung hauptsächlich von befristeter Einstiegsarbeit betroffen ist und (2) inwiefern dies lohntechnische Konsequenzen zur Folge hat. Die Resultate zeigen, dass sich Arbeitsmarkteinstiege über befristete Jobs mit tiefem beruflichem Status negativ auf das spätere Lohnniveau auswirken.

Schlüsselwörter: befristete Arbeit, Arbeitsplatzunsicherheit, Arbeitsmarkteinstieg, berufliche Grundbildung, Löhne

\section{Emploi à durée déterminée à la suite de la formation professionnelle en Suisse : tremplin ou obstacle?}

Résumé: Des positions contradictoires persistent dans la littérature quant à savoir si les emplois à durée déterminée constituent ou non un début favorable de carrière professionnelle. Basé sur l'enquête longitudinale TREE, cet article examine (1) qui sont les diplômés de formation professionnelle intégrant le marché du travail par un emploi à durée déterminée et (2) quelles conséquences ce premier engagement a sur le futur salaire. Les résultats montrent qu'un premier engagement à durée déterminée a des conséquences négatives s'il s'agit d'un emploi de bas statut professionnel.

Mots-clés: emploi à durée déterminée, travail précaire, intégration au marché du travail, formation de base professionnelle, salaires

\footnotetext{
* Social Research and Methodology Group, University of Basel, CH-4051 Basel, laura.helbling@ unibas.ch.

1 I would like to thank Christian Imdorf and Stefan Sacchi as well as the anonymous reviewers for their helpful comments and Katrien Van den Bergh for proofreading. I further thank the Swiss National Science Foundation (SNSF) for funding this study.
} 


\section{Introduction}

In response to an increased demand for flexible employment, greater flexibilisation and deregulation are characteristic of recent changes in the world of work. In this context, the erosion of standard employment relationships in favour of an increase in new flexible forms of employment (see e. g., Diekmann and Jann 2005) has become a controversially debated topic and a core contemporary concern (Kalleberg 2009).

Despite increased educational attainment, transitions from school to work seem to be particularly affected by these recent trends. Young labour market entrants encounter increasing difficulties in finding stable employment across OECD countries (Blossfeld 2006; Blossfeld et al. 2008), a phenomenon which no longer only affects the most marginalised entrants who lack educational qualifications. Focusing on Switzerland, with its educational system's strong vocational orientation (see Stalder and Nägele 2011) and comparatively low youth unemployment rates (OECD 2013a), recent findings suggest that vocational education and training (VET) graduates face increasing difficulties in setting foot in the Swiss labour market due to increasing job requirements (Salvisberg and Sacchi 2014). While fixed-term employment may, in this regard, help newcomers bridge the transition from school to work, the downside may be that fixed-term entry jobs become a trap leading to cycles of repeat fixed-term work and unemployment (OECD 1998). Apart from career instability, fixed-term jobs may further be associated with inferior work, providing fewer opportunities for professional development (Booth et al. 2002; Giesecke and Groß 2003; Wilkens and Leber 2003; Giesecke and Groß 2004). Overall, theoretical expectations concerning the integrational power of temporary work at labour market entry are contradictory and empirical findings are mixed.

As graduates from vocational education have already proven their productive skills during their training, incentives to screen labour market entrants with VET credentials are presumably low, such that labour market entrance via fixed-term jobs is comparatively less prevalent among vocationally educated young adults (Giesecke and Groß 2003; Giesecke and Groß 2004; McGinnity et al. 2005). As yet, little is known about the role fixed-term contracts play among labour market entrants who pursued VET diplomas, a group which constitutes the majority of young labour market entrants in Switzerland.

To help close this gap, the focus of this paper is on both the determinants and consequences of entering the Swiss labour market via fixed-term jobs.

The following research questions are investigated:

(1) Who is selected into fixed-term employment after graduating from initial VET programmes in Switzerland?

(2) Does entering the labour market via fixed-term work indicate a bad start to work life in terms of lower wages later on? 
Apart from focusing on the general effects of initial fixed-term employment on future wage profiles, a further distinction is made between "low" and "not low" status fixed-term entry jobs. This distinction allows for a potential heterogeneity of consequences of fixed-term entry employment depending on the occupational status of the jobs entered.

To investigate these research questions, fixed-term work and school-to-work transitions in the Swiss context are first outlined briefly. Second, a review of the controversial theoretical perspectives and mixed empirical findings is given, introducing competing hypotheses on the integrational potential of fixed-term entry employment. Following this, the method and data used are introduced. Finally, results are presented, followed by a conclusion.

\section{The Swiss context: Fixed-term jobs and labour market entry}

After the post-war period, which was characterised by the organisation of work in the form of standard employment relationships ${ }^{2}$ (such as dependent permanent, full-time work), flexible forms of work have become an integral part of the Swiss labour market. Since 2001, fixed-term employment has become increasingly prevalent (Ecoplan 2007; Ecoplan 2010). Overall, 7.2\% of employees were engaged in fixed-term work in 2012, with large discrepancies across sectors (SFSO 2013). Both young and older employees have been found to be disproportionately engaged in fixed-term employment, as have many highly educated ${ }^{3}$ employees (Henneberger et al. 2004). As dismissal costs of the permanent work force are comparatively low in Switzerland (Henneberger et al. 2004; OECD 2013b), permanent jobs may not differ as much from temporary work in terms of job security and aspects of labour segmentation as in countries with a stronger protection of the permanent work force. Controlling for individual heterogeneity, no wage penalty for temporary jobs or lower participation in continuing professional training of fixed-term employees is found. The flip side of temporary work is, however, the higher unemployment risk associated with it (Henneberger et al. 2004). Overall, little is known about the determinants and consequences of fixed-term work in Switzerland, particularly when it comes to fixed-term employment at entry to the Swiss labour market.

Focusing on school-to-work transitions in Switzerland, vocationally trained young workers form the majority of labour market entrants. Two-thirds of youth pursue vocational education and training at the upper secondary level in Switzerland. Standard VET programmes in Switzerland take about 3-4 years to complete and are awarded with a federal VET diploma (Eidgenössisches Fähigkeitszeugnis).

2 This particularly concerns male employment.

3 Ecoplan (2007) points towards an overrepresentation of both low (lower secondary education) and highly educated (tertiary education) workers in Switzerland, where the former are more often employed on short fixed-term contracts. 
Optionally and additionally, young people can obtain a federal vocational baccalaureate (Berufsmaturität), which qualifies them to enrol in vocationally oriented education at the tertiary level such as that provided by the universities of applied sciences. Characteristic of Switzerland's VET system is that a very high share of initial vocational education is organised in the form of dual-tracks (apprenticeships), in which company-based training and school-based learning are combined (Stalder and Nägele 2011; SERI 2015). ${ }^{4}$ There are close links between VET programmes and occupations, channelling VET graduates into the occupations they were trained in at entry. Due to occupational specificity, company-based training and standardisation of vocational education, less on-the-job screening is necessary at labour market entry. Hence, VET graduates are generally less likely to be allocated to fixed-term employment compared to young adults who pursued a more general education (see e. g., Giesecke and Groß 2003; Giesecke and Groß 2004; McGinnity et al. 2005; Greppi et al. 2010). The role fixed-term contracts play among VET graduates remains an open question.

\section{$3 \quad$ Fixed-term jobs: Integration or bad start?}

Competing perspectives concerning the integrational or disintegrational potential of fixed-term employment persist in the literature. Hiring workers on fixed-term contracts has for example been described as a numerical flexibilisation strategy that allows employers to more easily adjust the size of their workforce to fluctuations in demand and shift increased market risks to employees who are not their regular core workers (Atkinson 1984; Kalleberg 2003). Employment relationships may also be divided into open and closed positions, where the latter are more sheltered from competitive market forces. In addition to higher job security, closed positions are characterised by above-market wages as well as internal career ladders (Sørensen 1983; Sørensen 2000). Distinguishing employment relationships based on their degree of closure, fixed-term employment is regarded as more open than permanent employment (Giesecke and Groß 2004) and thus less advantageous with regards to wealth acquisition and promotion prospects. Based on segmentation theories, which posit a division of the labour market into primary and secondary segments, a similar picture of fixed-term work can be drawn. Jobs located in primary segments offer good career prospects and high wages, whereas job insecurity is thought to characterise inferior work in secondary segments. Barriers to mobility between segments are assumed to exist, hindering upward mobility out of insecure and inferior work (Doeringer and Piore 1971; Sengenberger 1979).

$4 \quad$ Differences exist across linguistic regions. VET and in particular dual VET have a very strong tradition in the German-speaking area, while it is somewhat less widespread and socio-culturally rooted in the Italian- and French-speaking parts of Switzerland (see e. g., SERI 2015). 
In addition, the transfer of labour market risks, for which employees are not compensated, is not regarded as being evenly distributed among employees, following lines of pre-existing social inequalities instead (Breen 1997). DiPrete et al. (2006) argue that European labour markets deal with increased macro-economic uncertainties especially through the allocation of low-skilled workers to insecure jobs. When searching for jobs, it can be expected that people tend to refuse unfavourable job offers when chances are good for alternative and more attractive job opportunities. In this vein, besides socially stratified risk shifting, employees' willingness to accept fixed-term job offers and compromise on job security may also be assumed to depend on their relative bargaining position in the labour market (see Auspurg and Gundert 2015). Following this reasoning, allocation to fixed-term employment may be expected to particularly affect workers with lower bargaining power (hypothesis $1)$, intensifying existing social inequalities.

Not confining increased job insecurity to the peripheral workforce, other theoretical perspectives posit a more general expansion of precarisation processes (Marchart 2013), affecting more and more workers who in former times would have been well integrated, enlarging the zone of vulnerability (Castel 2000). What connects these perspectives is the association of fixed-term jobs with insecure and presumably instable labour market integration. In line with this, fixed-term jobs are expected to indicate a bad and precarious start for labour market entrants (hypothesis 2.1) - be it in terms of their location in secondary segments and lower career prospects or because of employment instability in early career, which hinders continuous accumulation of work experience.

Empirical evidence generally supports the view that labour market entrants and young workers are overrepresented in insecure employment (see e. g., Blossfeld 2006). Investigating people's willingness to accept fixed-term employment based on an experimental vignette study conducted in Germany, findings further support the hypothesis that low bargaining power fosters the propensity to accept fixed-term job offers. Low qualifications and social class position as well as fewer financial resources and the experience of unemployment have all been found to increase the willingness to accept fixed-term employment (see Auspurg and Gundert 2015). Findings also show that the skill-related composition of the workforce in temporary work differs across European countries and institutional settings (Gebel and Giesecke 2011). Overall, findings suggest that vocationally skilled graduates are comparatively less affected by fixed-term employment at entry to the labour market (see section 2). It remains an open question, however, whether certain groups among VET graduates with presumably lower bargaining power may still be disproportionately affected by employment of a contractually limited duration in comparison to their peers. Factors determining the bargaining power of VET graduates may relate to their socio-economic standing with regard to their family background, migrant status, their gender or how demanding their lower secondary education and vocational 
education is. While socio-economic standing and educational achievement are assumed to be positively related with bargaining power, migrant status and female gender may be connected to lower bargaining power vis-à-vis employers. Further, experiences of unemployment and extended job searches may influence VET graduates' willingness to accept fixed-term job offers (see Auspurg and Gundert 2015).

In addition, fields of vocational programmes that are closely linked to occupations open up differing employment prospects for VET graduates (Kriesi et al. 2010).

Different empirical findings support an association between fixed-term work, employment instability and social inequality across different national contexts and institutional settings. In both the UK and Germany, temporary jobs have been found to lead to an increased risk of unemployment, repeat fixed-term work and worse pay (Booth et al. 2002; Giesecke and Groß 2003; Giesecke and Groß 2004), with wage penalties already extending to initial wages (see Gebel 2009; Gebel 2010). Moreover, fixed-term employees have been found to be less satisfied with their jobs with regards to job security and promotion prospects as well as to receive less workrelated training (Booth et al. 2002; Wilkens and Leber 2003). For Switzerland (see section 2), findings are suggestive of a higher unemployment risk associated with fixed-term work (Henneberger et al. 2004). Focusing on school-to-work transitions, the introduction of fixed-term contracts in France is not seen as a successful strategy in reducing youth unemployment, as it goes together with a high turnover in entrylevel jobs (Blanchard and Landier 2002). All in all, these empirical findings are suggestive of negative effects of initial fixed-term work on subsequent employment prospects, lending support to hypothesis 2.1, assuming fixed-term jobs to indicate a bad start for labour market entrants.

In contradiction to theoretical assumptions positing a link between fixed-term employment and unfavourable employment prospects, the viewpoint of an integration scenario (Giesecke and Groß 2003) also exists. In this perspective, contracts of limited duration serve as screening devices that allow labour market outsiders, such as e.g. new entrants and the unemployed, to more easily (re)enter the labour market. If there are initial disadvantages, such as lower wages, fewer training opportunities and higher job insecurity, attached to fixed-term entry jobs, these are thought to be overcome in the subsequent career. In line with the integration scenario, McGinnity et al. (2005) find that the unemployment rates of those who start their occupational career on a temporary contract converge after five years with those who started their career on a permanent job in Germany. Furthermore, fixed-term jobs have been found not to hinder upward mobility in terms of occupational prestige (see Scherer 2004), and initial wage differentials vanish over time (see Gebel 2010). As screening via fixed-term entry jobs may particularly apply to academically educated entrants who first need to prove their performance on the job, it may be questionable whether the integration scenario also applies to VET graduates (see e. g., Gebel 2010). According to the integration scenario, however, temporary jobs at labour market entry 
may also be thought of as easing the school-to-work transition for young VET graduates (hypothesis 2.2), who, after a prolonged probation period, have a good chance of becoming employed on permanent contracts and experiencing no impediment to their career advancement and subsequent wages.

Workers employed in non-standard work arrangements differ in terms of their autonomy and control over their work and skills (Kalleberg 2003) and their employability (McQuaid and Lindsay 2005) in case of job loss. Thus, job insecurity may not uniformly mirror employment insecurity (see Chung 2015). Further, different operational logics of fixed-term employment (see Giesecke and Groß 2006) - such as whether employers utilise fixed-term hiring for reasons of flexible adjustment or as initial screening - may co-exist, and their utilisation may vary across industries and according to the bargaining power of employees. Going beyond an either-or perspective on the implications of fixed-term employment, the concept of a twotier labour market of fixed-term jobs encompassing high and low wage fixed-term employment (Mertens and McGinnity 2003) is suggestive of a division of temporary jobs into secondary and primary work (Kunda et al. 2002). While low status fixedterm jobs at the bottom end may hinder subsequent career prospects, contracts of limited duration pertaining to jobs of a "not low" status may be part of a career progression, not hindering the career advancement of young people (hypothesis 2.3).

In summary, competing theoretical expectations about the consequences of fixed-term entry jobs exist. When fixed-term work is associated with employment instability and secondary labour, entering the labour market via fixed-term jobs is expected to hinder career advancement and endanger the labour market integration of young people. In this context it can be assumed that particularly young entrants who lack bargaining power are allocated to fixed-term jobs at entry. Based on the integration scenario, which associates fixed-term employment with prolonged probationary periods, no lasting adverse consequences should be expected. Beyond these conflicting theoretical perspectives, fixed-term entry jobs may also be regarded as heterogeneous in their integrational or disintegrational potential. Depending on young entrants' employability and the occupational status of jobs entered, different scenarios may apply.

\section{Method}

When investigating the consequences of fixed-term entry jobs, particular attention needs to be paid to non-random selection of VET graduates into fixed-term entry employment, making causal inferences about the effects of fixed-term entry jobs on subsequent career outcomes equivocal. This study tries to approximate the (causal) impact of fixed-term entry work on future wages (in 2010) applying endogenous treatment effect regression. Endogenous treatment effect regression is based on the 
work of Heckman (1978), which is concerned with a two-stage consistent estimation of causal effects in the case of selection on unobservables (see e. g. Heckman 1978; Vella 1998; Briggs 2004). The basic setup of the Heckman endogenous treatment model is as follows: ${ }^{5}$

The primary regression equation of interest:

$$
\ln \left(\text { wage }_{2010}\right)=x_{i} \beta+\delta d_{i(e n t r)}+\varepsilon_{i} \quad, \varepsilon_{i} \sim N\left[0, \sigma^{2}\right] \text { and } i=1 \ldots n \text { (individuals) }
$$

The selection equation:

$$
d_{i(\text { entry })}^{*}=z_{i} \gamma+u_{i} \quad d_{i(\text { entry })}=\left\{\begin{array}{c}
1, \text { if } d_{i(\text { entry })}^{*}>0 \\
0, \text { otherwise }
\end{array}, u_{i} \sim N[0,1]\right. \text { [Probit regression] }
$$

where $d_{\text {i(entry) }}$ is a binary treatment variable (fixed-term entry employment) and $d_{i(\text { entry })}^{*}$ is a latent variable assumed to underlie the treatment assignment process, while $z_{i}$ and $x_{i}$ are vectors of variables determining selection into fixed-term entry employment or subsequent wages, respectively. The errors $\left(\varepsilon_{i}, u_{i}\right)$ are assumed to have a bivariate normal distribution with correlation $p$, which is the correlation between unobservables determining the propensity to become employed fixed-term at entry and unobserved determinants of future wage offers. If $p \neq 0$, then the treatment variable $d_{i(\text { entry) }}$ is endogenous as it is correlated with $\varepsilon_{i}$ due to the correlation between $\varepsilon_{i}$ and $u_{i}$. Estimating $\delta$ based on the primary equation of interest would hence result in biased treatment effect estimates.

The strategy proposed by Heckman (1978) is to view sample selection bias as a form of omitted variable bias such that introducing a correction term for sample selection bias $\left(E\left[\varepsilon_{i} \mid x_{i}, d_{i(e n t r y)}, z_{i}\right]\right)$ as an additional variable in the primary regression equation allows for estimation of consistent treatment effects $\delta$.

Assuming joint normality of errors $\left(\varepsilon_{i}, u_{i}\right)$, the correction term for selection bias can be estimated based on the inverse Mills ratio $\lambda$ evaluated at estimates $\left(z_{i} \hat{\gamma}\right)$ from the selection equation: $E\left[\varepsilon_{i} \mid x_{i}, d_{i(\text { entry })}, z_{i}\right]=p \sigma \lambda_{i}$

$$
\widehat{\lambda}_{t}=\left\{\begin{array}{c}
\frac{\phi\left(z_{i} \widehat{\gamma}\right)}{\Phi\left(z_{i} \widehat{\gamma}\right)} \text { if } d_{i(\text { entry })}=1 \\
\frac{-\phi\left(z_{i} \widehat{\gamma}\right)}{1-\Phi\left(z_{i} \widehat{\gamma}\right)} \text { if } d_{i(e n t y)}=0
\end{array}\right.
$$

where $\phi(\cdot)$ and $\Phi(\cdot)$ denote the density and distribution function of the standard normal distribution.

Including this correction term for sample selection bias, the "selection bias" corrected outcome regression is:

$5 \quad$ Parameters can be estimated by either a two-step estimation procedure (following the basic setup outlined) or maximum likelihood. The latter was applied in the analysis reported (for the formula of the likelihood function, see Stata 2013, 28). 


$$
\ln \left(\text { wage }_{2010}\right)=x_{i} \hat{\beta}+\hat{\delta} d_{i(\text { entry })}+\hat{g} \widehat{\lambda}_{i}+e_{i} \text {, where } \hat{g}=\hat{p} \hat{\sigma}
$$

Concerning identification, the covariates included in the selection equation may not necessarily differ from those included in the outcome equation, as the Heckman endogenous treatment model is identified through the nonlinearity inherent in the inverse Mills ratio. However, identification based solely on the inverse Mills ratio is weak (see e. g. Vella 1998; Briggs 2004). Several authors thus recommend exclusion restrictions, such as the inclusion of (at least) one variable within the selection equation which is excluded from the second-stage outcome regression. This comes down to finding potential "instrumental" variables explaining selection into fixedterm employment while not directly impacting on future wages. As one may not easily find an incontestable "instrumental variable" for selection into fixed-term entry employment and as results based on the Heckman endogenous treatment model may be sensitive to violations of the distributional assumptions, drawing causal inference regarding the effects of fixed-term entry employment on future wages remains a risky business. As the Heckman model is known to be sensitive to the model specification (exclusion restrictions) (see e. g. Briggs 2004), results based on different model specifications (M1-M3) are reported. For further comparison, estimates from a linear model (OLS) with no Heckman correction are shown. The latter model relaxes assumptions of normality of the error term while it requires the assumption of no selection on unobservables to be met. The detailed list of variables (see appendix) makes it possible to control for a diverse set of potential confounders and hence increases the credibility of these results.

To further allow for potentially heterogeneous treatment effects among VET graduates who enter "low" or "not low" status fixed-term entry jobs, an interaction term between the contractual and occupational statuses of the entry job is additionally included in the outcome regression model. Based on this interaction, separate treatment effects for the subgroups of VET graduates who entered the labour market via jobs of "low" or "not low" occupational status are estimated. ${ }^{6}$

\section{Data and sample}

The analysis is based on data provided by TREE (Transition from Education to Employment), which is a unique, longitudinal survey that follows the school-towork transitions of approximately 6000 pupils who participated in PISA 2000 (Programme for International Student Assessment) and who left compulsory schools in the same year. These pupils were then followed annually from 2001-2007 by

6 For estimation, the etregress command in the software framework of stata 13 is used. Making use of the svy-commands provided by stata, correction for the complex survey design of the PISA/ TREE survey regarding variance estimation and weights correcting for disproportionality due to sampling design and panel attrition are applied (see Sacchi 2011). 
TREE, with two additional surveys taking place in 2010 and 2014 (TREE 2013).7 The analysis is restricted to a subsample of labour market entrants who completed a first vocational education and entered the labour market by the year 2007 . The focus is on the first significant job (of more than three months' tenure) entered after graduation from VET. This first job had to be reported in both the job episode data and the yearly survey of TREE, such that information on contractual status is available. Concerning vocational education, both standard three-to-four year apprenticeship programmes as well as apprenticeship programmes followed by a vocational baccalaureate are included.

The main sample on which the investigation of selection into fixed-term employment after vocational education is based consists of 1462 young entrants (782 women and 680 men). Out of these young entrants, 232 started their careers on a contract of limited duration. Focusing on their initial vocational education reveals that 1143 pursued an apprenticeship programme, ${ }^{8}$ while 319 additionally obtained a vocational baccalaureate.

Endogenous treatment effect analysis focusing on wages earned in the year 2010 , when the young adults were about 26 years old, is restricted to the 563 young adults still followed up by TREE and who answered the complementary employment questionnaire providing information on their earnings. ${ }^{9}$

\subsection{Variables and model specifications}

The binary variable fixed-term contract is coded as 1 if the first significant job after graduating from VET is reported to be of a contractually limited duration, while it is coded 0 if the contractual status of the first job is of a permanent nature. ${ }^{10}$ Wages are measured as monthly full-time equivalent gross earnings, which were calculated according to Bertschy et al. (2014). In order to allow for heterogeneity in consequences of fixed-term employment, a distinction between "low" and "not low" status fixed-term entry jobs is made based on the international socio-economic index (ISEI) (see Ganzeboom et al. 1992). ISEI scores below 40 (which corresponds to the mean occupational status of those starting their career on fixed-term jobs) are

$7 \quad$ Data for the latest survey has not been released at submission of this article. Response rates of the survey in 2010 amount to $75 \%$ responding of those contacted in 2010 and to $54 \%$ responding compared to the sample contacted in the first TREE survey in 2001 (see TREE 2013, 11).

8 Fifty-four young adults pursued two apprenticeship programmes successively, while 75 young VET graduates pursued another (non-certifying) education (e. g. language courses, trainings etc.) before entering a first significant job.

9 Two persons who indicated earning exceedingly high incomes in 2010, which did not match their occupations and education, were excluded. Actual numbers on which the analysis is conducted further diverge as respondents with missing values on relevant covariates are excluded.

10 The variable on fixed-term jobs encompasses different forms of contractually limited employment, including e.g. seasonal/casual work, substitution, project work, temporary agency work conducted on a fixed-term contract as well as work that could in principle be carried out on a permanent basis but is done on a fixed-term contract. Training episodes are not included as fixed-term entry jobs. 
regarded as "low" status fixed-term entry jobs, while those equal to or above an ISEI of 40 are regarded as "not low" status fixed-term entry jobs.

Making use of endogenous treatment effect regression, different model specifications (M1-M3) were introduced (details concerning covariates included as well as descriptive statistics can be found in the appendix).

In the first model specification (M1), the fixed-term employment rate among young people holding a VET diploma (aggregate measure based on SAKE data) and the youth unemployment rate (see SFSO 2016) at year of graduating from VET enter the selection equation, while these covariates are excluded from the outcome equation. Thus it is assumed that these entry conditions predict selection into fixed-term employment, while they are not confounders at the second stage. After inclusion of further covariates in the selection function, no significant effect of these entry conditions on selection into fixed-term entry employment is found. Thus these entry conditions are only weak predictors of assignment to fixed-term employment of VET graduates in the data at hand.

M1: Selection eq. (fixed-term entry job): (explanatory variables: gender, migrant background, parental ISEI, PISA index of social communication at home [soccom], lower secondary education track, PISA reading literacy [wleread], level of VET, tertiary education, dual VET, field of VET, further diploma, transitional unemployment, duration until first job, firm size, self-efficacy and persistency, linguistic region, year of labour market entry, fixed-term and youth unemployment rate at year of graduation $\left.{ }^{11}\right)$, Outcome eq. (In[wage $\left.\left.{ }_{2010}\right]\right)$ : (explanatory variables: excluding fixedterm rate and youth unemployment rate at graduation, otherwise same covariates as in the selection equation + tertiary education).

In the second model specification (M2), covariates included in the outcome equation are further reduced compared to the selection equation. This further reduction in order to improve on meeting exclusion restrictions comes at the cost of stronger assumptions concerning possible confounding. Variables excluded from the second stage, such as e.g. social background factors, may exert a direct effect through social contacts and networking on job quality and wages. Initial unemployment experiences may be scarring and initial placement in firms of differential sizes may also be assumed to determine future careers and wages. Hence, while this model specification technically meets exclusion restrictions, assumptions about the absence of confounding effects of covariates excluded from the outcome equation are not incontestable.

11 Youth unemployment rate and fixed-term rate at graduation (aggregate measures) are to some extent correlated with the year of labour market entry (year of first job). Excluding the year of entry from the selection equation and/or the outcome equation as well as including either only the fixed-term rate or only the youth unemployment rate at graduation does not alter the results. In addition, measures for yearly and cantonal youth unemployment rates were included, but these do not provide a stronger predictor for initial fixed-term employment, and results remain the same. 
M2: Selection eq. (fixed-term entry job): (explanatory variables: as in M1), Outcome eq. (In[wage $\left.\left.{ }_{2010}\right]\right)$ : (explanatory variables reduced to: gender, migrant background, level of VET, tertiary education, field of VET, linguistic region, year of labour market entry)

Concerning the third model specification (M3), a model is estimated which does not meet exclusion restrictions concerning the selection function. Here, no strong assumptions on the absence of confounding of excluded variables are necessary. This however comes at the cost that this model is only weakly identified:

M3: Selection eq. (fixed-term entry job): (explanatory variables: as in M1), Outcome eq. (In[wage $\left.\left.{ }_{2010}\right]\right)$ : (explanatory variables: same as in selection equation + tertiary education)

Furthermore, as a fourth model for comparison linear regression (OLS) with no Heckman correction is applied, assuming that after adjusting for the covariates reported (see appendix) there is no further confounding due to unobservables.

\section{Results}

\subsection{Who enters the Swiss labour market via fixed-term employment after VET?}

Focusing first on those among the VET graduates who enter the labour market via fixed-term employment, this section provides insight into whether or not these more insecure entry jobs may be targeted at vocationally skilled young entrants with presumably lower bargaining power in the Swiss labour market (hypothesis 1). In Table 1, average marginal effects (AMEs) are presented, which were estimated based on a probit regression analysis. The covariates included in this probit regression represent those of the selection equation introduced in the following endogenous treatment effect analysis. ${ }^{12}$ Contrary to hypothesis 1 , the empirical results do not support the idea that fixed-term contracts are more often assigned to VET graduates who lack bargaining power.

Findings reveal that young graduates born in Switzerland are on average 9\% more likely to become employed fixed-term at labour market entry, when controlling for further covariates included in the model. Moreover, results suggest that parental socio-economic status is significantly positively related to starting a career on a fixed-term job. ${ }^{13}$ Focusing on the reading skills of the young shows that, when

12 To describe the selection process (hypothesis 1), all VET graduates for whom there is information on relevant variables to model their entry into their first job (contractual status) are included. One may note that the endogenous treatment effects analysis (selection and outcome regression), which is concerned with employment outcomes some years later (hypotheses 2.1-2.3) is applied to a reduced sample comprised of those still in the TREE survey in 2010, providing information on their wages. To correct for panel attrition, respective survey weights are applied (see Sacchi 2011).

13 Not controlling for other variables still reveals an overrepresentation of Swiss-born VET graduates in fixed-term employment, but the effect of country of birth is not significant. Similarly, when 
controlling for further covariates included, the reading skills of those assigned to fixed-term jobs seem to be somewhat lower. Young VET graduates who pursued a highly demanding vocational education as well as those who completed a vocational baccalaureate are on average 15\% more likely to become employed on a fixed-term first job compared to young entrants who pursued less demanding vocational education. To some degree this also applies to those who completed moderately demanding vocational education, who are $6 \%$ more likely to become employed on a fixed-term contract compared to young entrants who pursued less demanding vocational education (significant at $\mathrm{p} \leq 0.1$ ).

The higher exposure to fixed-term entry employment of VET graduates who completed VET at a higher level of demand particularly comes to the fore when controlling for fields of the vocational training pursued. Overall, the majority of VET graduates pursued their vocational education in the fields of business \& sales and mechanics, electronics \& construction. Particularly within these two fields, it is those who pursued highly demanding VET or who further obtained a vocational baccalaureate that are more likely to start their career on a fixed-term job compared to their peers who completed less demanding VET.

The fields of vocational education and training also matter in themselves. Young VET graduates who pursued their training in the field of printing \& design and those who pursued their training in the field of information technology are $10 \%$ and $8 \%$, respectively, less likely to become employed on a first temporary contract compared to young entrants who pursued their education in the field of business \& sales. In contrast, young entrants who pursued their training in the field of agriculture $\&$ gardening or in the field of gastronomy \& hairdressing are $38 \%$ and $27 \%$ more likely, respectively, to start their career on a contract of limited duration. ${ }^{14}$ In these occupational fields, the higher prevalence of fixed-term employment may mirror employers' needs for more flexible adaptation to fluctuations in demand. Overrepresentation of fixed-term entry employment in these respective fields of training may relate to the lower bargaining power of graduates who mainly pursued less demanding vocational training and do not face very good employment and career prospects in the Swiss labour market (see e. g., Sacchi and Salvisberg 2014 on employment prospects in the field of services). This result is suggestive of some division in the selection of VET graduates with differing levels of bargaining power into fixed-term employment, which may coincide with differential operational logics behind fixed-term entry work.

Results further show that the size of the firm one starts one's occupational career in also plays an important role in determining the type of first contract. Young adults entering work life in a small-sized firm are $10 \%$ less likely to enter a

not controlling for further covariates, parental socio-economic status is still positively but not significantly associated with initial fixed-term employment.

14 Some caution in the interpretation of results for the different VET fields is required, particularly for the fields of printing $\&$ design, information technology and agriculture $\&$ gardening, due to small numbers. 
Table $1 \quad$ Probit Regression / selection into fixed-term employment

\begin{tabular}{|c|c|c|}
\hline Fixed-term entry job & AME & SE \\
\hline Gender (male $=1$ ) & -0.02 & 0.03 \\
\hline Migrant background (yes $=1$ ) & 0.08 & 0.07 \\
\hline Country of birth $(\mathrm{CH}=1)$ & $0.09^{*}$ & 0.04 \\
\hline Parental ISEI & $0.002^{* *}$ & 0.001 \\
\hline Soccom (PISA-index) & 0.02 & 0.02 \\
\hline \multicolumn{3}{|l|}{ Lower secondary education (ref. basic requirements) } \\
\hline extended requirement & -0.03 & 0.03 \\
\hline non formal & -0.06 & 0.05 \\
\hline PISA literacy score & $-0.0004^{*}$ & 0.0002 \\
\hline \multicolumn{3}{|l|}{ Upper secondary education (ref. low level of VET) } \\
\hline medium-skill VET & $0.06\left(^{*}\right)$ & 0.04 \\
\hline high-skill VET & $0.15^{* * *}$ & 0.04 \\
\hline BMS (vocational baccalaureate) & $0.15^{* *}$ & 0.05 \\
\hline Dual VET (yes $=1$ ) & -0.03 & 0.06 \\
\hline Further education/training before entry (yes $=1$ ) & 0.07 & 0.08 \\
\hline Self-efficacy (high =1) & -0.02 & 0.04 \\
\hline Persistency (high =1) & 0.003 & 0.03 \\
\hline Unemployment experiences (yes $=1$ ) & -0.02 & 0.06 \\
\hline Duration in months & -0.001 & 0.003 \\
\hline \multicolumn{3}{|l|}{ Field of VET (ref. business \& sales) } \\
\hline printing \& design & $-0.10^{* * *}$ & 0.02 \\
\hline information technology & $-0.08^{* *}$ & 0.02 \\
\hline mechanics, electronics \& construction & -0.01 & 0.03 \\
\hline agriculture \& gardening & $0.38^{* * *}$ & 0.11 \\
\hline medical assistance & -0.04 & 0.05 \\
\hline gastronomy \& hairdressing & $0.27^{* * *}$ & 0.07 \\
\hline \multicolumn{3}{|l|}{ Firm size (headcount) ( ref. large [100+]) } \\
\hline small [0-9] & $-0.10^{*}$ & 0.04 \\
\hline medium [10-99] & -0.03 & 0.04 \\
\hline \multicolumn{3}{|l|}{ Year of labour market entry (ref. 2003/2002) } \\
\hline 2004 & $0.10^{* *}$ & 0.03 \\
\hline 2005 & $0.09^{*}$ & 0.04 \\
\hline 2006 & 0.01 & 0.05 \\
\hline 2007 & 0.001 & 0.07 \\
\hline Fixed-term ratio at graduation & 0.001 & 0.01 \\
\hline Youth unemployment at graduation & 0.02 & 0.02 \\
\hline
\end{tabular}


Continuation of Table 1.

\begin{tabular}{lcc}
\hline Fixed-term entry job & AME & SE \\
\hline Region of residence (ref. German-speaking part) & & \\
French-speaking part & 0.01 & 0.03 \\
Italian-speaking part & $-0.06^{* *}$ & 0.02 \\
$N=1284$ & & \\
\hline
\end{tabular}

Notes: ${ }^{* * *} p \leq 0.001{ }^{* *} p \leq 0.01{ }^{*} p \leq 0.05\left(^{*}\right) p \leq 0.1 ; \mathrm{AME}=$ average marginal effects, SE $=$ standard errors. Source: TREE, own calculations.

fixed-term entry job compared to those who start their career in a large-sized firm, which may be indicative of higher exposure among large firms to international competition (see Gebel 2010). Last but not least, results suggest some discrepancies regarding selection into fixed-term jobs across entry years and point to the fact that young entrants living in the Italian-speaking part of Switzerland are somewhat less likely to become employed on a fixed-term contract compared to those living in the German-speaking part. ${ }^{15}$

\subsection{Fixed-term entry jobs: do they adversely impact wage development?}

Turning to wages earned later in one's career, findings reveal a negative average treatment effect (ATE) of entering work life via fixed-term employment (significant at $\mathrm{p} \leq 0.1$ ). Controlling for selection on unobserved factors as well as for the covariates additionally included in the second-stage outcome regression based on the endogenous treatment effects models specified (M1-M3), starting a career on a fixed-term contract is found to be associated with a predicted earnings disadvantage of about $9-10 \%{ }^{16}$ (around CHF 470) in the year 2010, when the former entrants are about 26 years old (see Table 2). The correlation coefficient is not found to be significant in all three models (M1-M3) specified. This suggests that no selection bias on unobservables is present (under the maintained distributional assumptions and the covariates included). Estimates based on linear regression (OLS) with no Heckman correction suggest lower earnings of about $8 \%$ for those who entered the

15 Results reported were estimated applying a customised and truncated weight (for details cf. Sacchi 2011,22) based on the panel weights for the survey years of labour market entries observed. One may note that applying a weight (basewt) which only corrects for disproportionality due to the sampling design but not for panel attrition would lead to the additional finding that male graduates might be somewhat overrepresented in fixed-term entry jobs and lead to the finding that those who completed a dual VET (company and school-based) are less likely to start their career on a fixed-term job compared to those who did a purely school-based VET. 
labour market via fixed-term employment (statistically significant at $\mathrm{p} \leq 0.05$ ) (see Table 2). ${ }^{17}$

Estimation of separate average treatment effects for VET graduates who entered "low" versus "not low" status fixed-term entry jobs allows for further insight into potentially heterogeneous effects of fixed-term employment at labour market entry. Results suggest that average treatment effects estimated for VET graduates who entered "low" versus "not low" status jobs differ significantly in size. While average treatment effects estimated for those who entered a "low" status first job reveal a significantly negative impact of starting a career in a fixed-term job on later wages, there seem to be no disadvantages attached to starting the career on a fixed-term contract in a "not low" status first job (see Table 3). On average, VET graduates who enter a fixed-term "low" status job earn a predicted $13-14 \%{ }^{18}$ (about CHF 680) less compared to VET graduates who entered a permanent "low" status job at first. In contrast, VET graduates who enter a fixed-term job of a "not low" occupational status do not earn less than their peers who started their career in a permanent job of comparable occupational status. Thus results suggest that the effects of fixed-term entry employment on future wages depend on the status of the entry job. ${ }^{19}$ The negative impact of entering work life via fixed-term jobs seems to mainly affect VET graduates who do so in lower status fixed-term jobs. ${ }^{20}$

17 Descriptively comparing wages earned in 2010 across those initially employed fixed-term (earning CHF 4921) vs. permanently (earning CHF 5226), a wage difference of (6\%) CHF 305 to the disadvantage of those initially employed fixed-term is found. Hence, while this descriptive result points in the same direction as the multivariate results, the descriptive wage gap may be biased slightly downward due to the positive (although not significant) selection into initial fixed-term employment present in the data.

18 See footnote 16.

19 Descriptive statistics support a similar conclusion. Comparing the wages earned in 2010 by those initially employed fixed-term who entered the labour market in "low" status jobs (earning CHF 4921) to those who engaged in permanent jobs of "not low" status (earning CHF 5260), a wage difference of (16\%) CHF 839 to the disadvantage of those initially employed fixed-term is found. Comparing the wages of young workers who entered the labour market in "not low" status fixed-term jobs (earning CHF 5397) to the wages of young workers who first engaged in "not low" status permanent jobs (earning CHF 5224), no wage disadvantage to the detriment of initially fixed-term employed is found - rather, they seem to even earn slightly higher wages of (3\%) CHF 173.

20 Heterogeneous average treatment effects (Table 3) are estimated based on small group sizes. Of those who started their career on a fixed-term job and whose later wages are known, about 44 respondents did so in a "not low" status fixed-term entry job, compared to 52 who entered the labour market via a "low" status fixed-term job. Thus, estimated separate average treatment effects should be regarded with caution and may only serve as an indication of potential heterogeneity in effects of initial fixed-term employment. 
Table $2 \quad$ In(wage) differences by fixed-term entry employment

\begin{tabular}{llrrr}
\hline Model specification & ATE: Fixed-term entry job & SE & $\rho$ & SE \\
\hline M1: In(wage) difference & $-0.09\left(^{*}\right)$ & 0.05 & 0.04 & 0.07 \\
M2: In(wage) difference & $-0.10\left(^{*}\right)$ & 0.05 & 0.06 & 0.10 \\
M3: In(wage) difference & $-0.09\left(^{*}\right)$ & 0.05 & 0.03 & 0.08 \\
OLS: In(wage) difference & $-0.08^{*}$ & 0.03 & - & - \\
\hline
\end{tabular}

Notes: $N=510 ;\left({ }^{*}\right) p \leq 0.1{ }^{*} p \leq 0.05$, see model specifications (M1-M3, OLS) in section $5.1 ; A T E=$ average treatment effect, $\mathrm{SE}=$ standard errors.

Source: own calculations.

Table 3

In(wage) differences: Heterogeneous effects of fixed-term entry jobs

\begin{tabular}{lcr}
\hline Model specification & ATE: Fixed-term entry job & SE \\
\hline M1: In(wage) difference: "not low" status entry jobs & 0.01 & 0.05 \\
M1: In(wage) difference: "low" status entry jobs & $-0.14^{*}$ & 0.07 \\
M2: In(wage) difference: "not low" status entry jobs & -0.01 & 0.05 \\
M2: In(wage) difference: "not low" status entry jobs & $-0.15^{*}$ & 0.06 \\
M3: In(wage) difference: "not low" status entry jobs & 0.02 & 0.06 \\
M3: In(wage) difference: "not low" status entry jobs & $-0.14^{*}$ & 0.07 \\
OLS: In(wage) difference: "not low" status entry jobs & 0.02 & 0.04 \\
OLS: In(wage) difference: "low" status entry jobs & $-0.14^{*}$ & 0.05 \\
\hline
\end{tabular}

Notes: ${ }^{*} p \leq 0.05$, see model specifications (M1-M3, OLS) in section $5.1 ; A T E=$ average treatment effect, $\mathrm{SE}=$ standard errors.

Source: TREE, own calculations.

\section{Conclusion}

In the literature on the consequences of fixed-term entry jobs, two contradictory expectations persist. On the one hand, fixed-term employment is associated with inferior work, fewer career prospects and employment instability (see e. g. Booth et al. 2002, Giesecke and Groß 2003; Wilkens and Leber 2003; Giesecke and Groß 2004), such that unfavourable employment outcomes of entering work life via fixedterm jobs are to be expected. In a similar vein, it is often assumed that fixed-term employment - as a dimension of precarious work (see ILO 2012) - is particularly targeted at workers with lower bargaining power. On the other hand, based on the integration scenario (see Giesecke and Groß 2003), fixed-term entry jobs may be regarded as easing the transition from school to work for the young and not hindering their future career advancement or labour market integration. As vocationally trained 
young entrants (forming the majority of labour market entrants in Switzerland) are presumably less affected by initial screening, the role fixed-term contracts play after graduating from VET remains unclear. This article sheds light on (i) who among VET graduates enters the labour market via fixed-term employment in Switzerland and (ii) investigates whether fixed-term jobs after graduating from VET may be seen as career launching or hindering in terms of subsequent wages earned.

Empirical results contradict hypothesis 1, which assumed fixed-term jobs to be particularly assigned to VET graduates lacking bargaining power, such as e. g. those who grew up in families with a lower socio-economic status, migrants and young adults who pursued less demanding lower secondary education and less demanding vocational training. VET graduates with better career prospects in general, such as those who pursued highly demanding vocational education and graduates who further obtained a vocational baccalaureate, as well as Swiss-born VET graduates and those with higher parental socio-economic standing, are more likely to take up fixed-term employment at first, with differences existing across fields of vocational training. Drawing on findings and considerations by Gebel (2010), one potential explanation may be that VET graduates who completed vocational education at a high level of demand and in particular those who obtained a vocational baccalaureate may plan to enrol in education at tertiary level after gaining some initial work experience, such that they may not in all cases be in search of a first permanent position. In light of the increasing job requirements affecting job prospects for VET graduates in Switzerland (Sacchi and Salvisberg 2014; Salvisberg and Sacchi 2014), another explanation may be that entry into more demanding jobs open to VET graduates who pursued more demanding vocational education may also be governed by some initial screening. Some less demanding occupational fields of training with comparatively worse employment and career prospects, such as agriculture $\&$ gardening or gastronomy \& hairdressing, also show some overrepresentation of VET graduates in fixed-term entry employment. Here, the operational logic of fixed-term employment as initial screening may not apply, suggesting that differences in operational logics and potential effects of fixed-term entry employment on subsequent careers across occupational segments and bargaining power of VET graduates may exist.

Focusing on consequences of initial fixed-term employment, making use of endogenous treatment effect regression, a tendency towards lower earnings in the mid-term for those who started their career on a fixed-term contract was found. Disentangling this tendency towards lower earnings by including occupational status as a moderator, findings are suggestive of heterogeneous effects of fixed-term entry jobs and thus favour hypothesis 2.3. It is particularly those young entrants who started their career in a "low" status fixed-term entry job that earn lower wages in the mid-term compared to their peers.

Why and how "low" status fixed-term entry jobs relate to lower future wages remains an open question. The operational logics of fixed-term employment that 
VET graduates engage in may differ, with lower status fixed-term jobs mirroring employers' needs for flexibilisation more closely, not providing an entry port into stable employment after initial contracts expire. Further, employment stability and internal career ladders may matter particularly for those who enter the labour market via lower status jobs. If the employability and bargaining power of workers engaging in lower status entry jobs is generally lower, they may also have more difficulties in quickly finding stable and good-quality jobs after their initial fixed-term contracts expire. For young workers with a lower status job of short tenure, these short employment spells may also be regarded as bad signals by future recruiting employers, who may see them as indicating lower productivity or motivation and thus hindering quick re-integration and career advancement. However, these are just assumptions, and empirical validation is left for future research.

As the occupation-specific VET diplomas acquired, qualifying the young for work in the occupational fields they were trained in, offer differential employment prospects and are to varying degrees affected by fixed-term (entry) work, future research may focus more specifically on the differential effects of fixed-term entry jobs across occupational segments. While in some occupational segments and industrial sectors, fixed-term entry jobs may be part of a career progression, not hindering upward mobility, they may endanger the labour market integration of the young in others. Due to sample-size restrictions, the data at hand did not allow for a more in-depth analysis regarding this point. Apart from labour market segmentation or employers' flexibilisation and screening strategies, the motives of the young themselves to engage in fixed-term work have so far been largely neglected in theoretical considerations and empirical research on fixed-term entry employment. Allowing more room for active agency, future research may also investigate the extent to which the young themselves look for or may even "bargain" for a fixed-term position due to plans for e. g. further education, traveling or military service. The present investigation was further concerned with differences in career advancement among VET graduates in the mid-term (when they were about 26 years old), and only future research can show whether the discrepancies found in wages will persist or if they are overcome in the longer run - potentially lending support to an integration scenario.

\section{References}

Atkinson, John. 1984. Manpower Strategies for Flexible Organizations. Personnel Management 16: $18-31$.

Auspurg, Katrin, and Stefanie Gundert. 2015. Precarious Employment and Bargaining Power: Results of a Factorial Survey Analysis. Zeitschrift für Soziologie 44(2): 99-117.

Bertschy, Kathrin, Philipp Walker, Annick Baeriswyl, and Michael Marti. 2014. Lohndiskriminierung beim Berufseinstieg. Eine quantitative Analyse für die Schweiz. Schweizerische Zeitschrift für Soziologie 40(2): 279-305. 
Blanchard, Olivier, and Augustin Landier. 2002. The Perverse Effects of Partial Labour Market Reform: Fixed-Term Contracts in France. The Economic Journal 112(480): 214-244.

Blossfeld, Hans-Peter. 2006. Globalisierung, wachsende Unsicherheit und die Veränderung der Chancen der jungen Generation in modernen Gesellschaften. Ausgewählte Ergebnisse des GLOBALIFEProjekts. Arbeit 15: 151-166.

Blossfeld, Hans-Peter, Sandra Buchholz, Erzsébet Bukodi, and Karin Kurz (Eds.). 2008. Young Workers, Globalization and the Labor Market: Comparing Early Working Life in Eleven Countries. Cheltenham: Edward Elgar.

Booth, Alison L., Marco Francesconi, and Jeff Frank. 2002. Temporary Jobs: Stepping Stones or Dead Ends? The Economic Journal 112(480): 189-213.

Breen, Richard. 1997. Risk, Recommodification and Stratification. Sociology 31: 473-489.

Briggs, Derek C. 2004. Causal Inference and the Heckman Model. Journal of Educational and Behavioural Statistics 29(4): 397-420.

Castel, Robert. 2000. Die Metamorphosen der sozialen Frage. Eine Chronik der Lohnarbeit. Konstanz: UVK.

Chung, Heejung .2015. Subjective Employment Insecurity Gap between Occupations: Variance across Europe. Pp. 271-297 in Non-Standard Employment in Post-Industrial Labour Markets. An occupational perspective, edited by Werner Eichhorst and Paul Marx. Cheltenham: Edward Elgar.

Diekmann, Andreas, and Ben Jann. 2005. The Erosion of Regular Work: An Analysis of the Structural Changes in the Swiss and German Labour Market. Pp. 190-217 in Contemporary Switzerland: Revisiting the Special Case, edited by Hanspeter Kriesi, Peter Farago, Martin Kohli, and Milad Zarin-Nejadan. Houndsmills: Palgrave Macmillan.

DiPrete, Thomas A., Dominique Goux, Eric Maurin, and Amelie Quesnel-Vallee. 2006. Work and Pay in Flexible and Regulated Labor Markets: A Generalized Perspective on Institutional Evolution and Inequality Trends in Europe and the U.S. Research in Social Stratification and Mobility 24: 311-332.

Doeringer, Peter B., and Michael J. Piore. 1971. Internal Labor Markets and Manpower Analysis. Lexington, MA: Heath.

Ecoplan (Economic Research and Policy Consultancy). 2007. Flexicurity: Bedeutung für die Schweiz. Beiträge zur Sozialen Sicherheit. Forschungsbericht 14/07. Bern: BSV.

Ecoplan (Economic Research and Policy Consultancy). 2010. Die Entwicklung atypisch-prekärer Arbeitsverhältnisse in der Schweiz. Nachfolgestudie zur Studie von 2003. Bern: Seco.

Ganzeboom, Harry B. G., Paul M. De Graaf, and Donald J. Treiman. 1992. A Standard International Socio-Economic Index of Occupational status. Social Science Research 21: 1-56.

Gebel, Michael. 2009. Fixed-Term Contracts at Labour Market Entry in West Germany: Implications for Job Search and First Job Quality. European Sociological Review 25(6): 661-675.

Gebel, Michael. 2010. Early Career Consequences of Temporary Employment in Germany and the UK. Work, Employment and Society 24(4): 641-660.

Gebel, Michael, and Johannes Giesecke. 2011. Labor Market Flexibility and Inequality: The Changing Skill-Based Temporary Employment and Unemployment Risks in Europe. Social Forces 90(1): $17-40$.

Giesecke, Johannes, and Martin Groß. 2003. Temporary Employment: Chance or Risk? European Sociological Review 19(2): 161-177.

Giesecke, Johannes, and Martin Groß. 2004. External Labour Market Flexibility and Social Inequality. European Societies 6(3): 347-382.

Giesecke, Johannes, and Martin Groß. 2006. Befristete Beschäftigung. WSI-Mitteilungen 5/2006. Düsseldorf: Hans-Böckler-Stiftung, http://www.boeckler.de/wsimit_2006_05_giesecke.pdf (05.02.2016).

Greppi, Spartaco, Mario Lucchini, Jenny Assi, and Christian Marazzi. 2010. The Determinants of FixedTerm Employment in Contemporary Switzerland. FORS Working Paper Series 2010-4. Lausanne: 
FORS, http://forscenter.ch/wp-content/uploads/2013/10/FORS_WPS_2010-04_Greppi-5.pdf (25.05.2016).

Heckman, James J. 1978. Dummy Endogenous Variables in a Simultaneous Equation System. Econometrica 46(4): 931-959.

Henneberger, Fred, Alfonso Sousa-Poza, and Alexandre Ziegler. 2004. Befristete Beschäftigung in der Schweiz. Ausmass, Determinanten und ökonomische Bewertung im internationalen Vergleich. Zeitschrift für Arbeitsmarktforschung 3: 239-267.

ILO (International Labour Office). 2012. From Precarious Work to Decent Work: Outcome Document to the Workers' Symposium on Policies and Regulations to Combat Precarious Employment. Geneva: ILO, http://www.ilo.org/wcmsp5/groups/public/---ed_dialogue/---actrav/documents/ meetingdocument/wcms_179787.pdf (16.06.2015).

Kalleberg, Arne L. 2003. Flexible Firms and Labor Market Segmentation: Effects of Workplace Restructuring on Jobs and Workers. Work and Occupations 30: 154-175.

Kalleberg, Arne L. 2009. Precarious Work, Insecure Workers: Employment Relations in Transition. American Sociological Review 74(1): 1-22.

Kriesi, Irene, Marlis Buchmann, and Stefan Sacchi. 2010. Variation in Job Opportunities for Men and Women in the Swiss Labor Market 1962-1989. Research in Social Stratification and Mobility 28(3): 309-323.

Kunda, Gideon, Stephen R. Barley, and James Evan. 2002. Why Do Contractors Contract? The Experience of Highly Skilled Technical Professionals in a Contingent Labor Market. Industrial and Labor Relations Review 55(2): 234-261.

Marchart, Oliver (Ed.). 2013. Facetten der Prekarisierungsgesellschaft. Prekäre Verhältnisse. Bielefeld: Transcript.

McGinnity, Frances, Antje Mertens, and Stefanie Gundert. 2005. A Bad Start? Fixed-Term Contracts and the Transition from Education to Work in West Germany. European Sociological Review 21(4): 359-374.

McQuaid, Ronald W., and Colin Lindsay. 2005. The Concept of Employability. Urban Studies 44(2): 197-219.

Mertens, Antje, and Frances McGinnity. 2003. A “Two-Tier” Labour Market for Fixed-Term Jobs? Evaluating Evidence from West Germany. Using Quantile Regression. Working Paper IZA 12. Berlin: Max-Planck-Institut für Bildungsforschung, http://www.iza.org/en/papers/Mertens200704. $\operatorname{pdf}(16.06 .2015)$.

OECD (Organisation for Economic Cooperation and Development). 1998. Getting Started, Settling In: The Transition from Education to the Labour Market. Pp. 81-122 in Employment Outlook, edited by OECD. Paris: OECD Publishing.

OECD (Organisation for Economic Cooperation and Development). 2013a. Youth Unemployment Rate. Employment and Labour Markets: Key Tables from OECD. Paris: OECD, http://www. oecd-ilibrary.org/employment/youth-unemployment-rate-2013-1_unemp-yth-table-2013-1-en (16.06.2015).

OECD (Organisation for Economic Cooperation and Development). 2013b. OECD Employment Outlook. Paris: OECD Publishing.

Sacchi, Stefan. 2011. Construction of TREE Panel Weights. Documentation for the Panel Waves from 2000-2010. Bern and Zurich: TREE and Cue Sozialforschung.

Sacchi, Stefan, and Alexander Salvisberg. 2014. Arbeitsmarktperspektiven von Fachkräften aus unterschiedlichen Berufen 2013. Report im Auftrag des Staatssekretariats für Bildung, Forschung und Innovation SBFI. Zurich: SMM.

Salvisberg, Alexander, and Stefan Sacchi. 2014. Labour Market Prospects of Swiss Career Entrants after Completion of Vocational Education and Training. European Societies 16(2): 255-274. 
Scherer, Stefani. 2004. Stepping-Stones or Traps? The Consequences of Labour Market Entry Positions on Future Careers in West Germany, Great Britain and Italy. Work, Employment and Society 18: 369-394.

Sengenberger, Werner. 1979. Zur Dynamik der Arbeitsmarktsegmentierung - mit Thesen zur Struktur und Entwicklung des Arbeitsmarktes in der Bundesrepublik Deutschland. BeitrAB 33: 1-44.

SERI (State Secretariate for Education, Research and Innovation). 2015. Facts and Figures 2015. Vocational and Professional Education and Training in Switzerland 2015. Bern: SERI.

SFSO (Swiss Federal Statistical Office). 2013. SAKE in Kürze 2012. Schweizerische Arbeitskräfteerhebung. Neuchâtel: BFS.

SFSO (Swiss Federal Statistical Office). 2016. Erwerbslosenquote gemäss ILO nach verschiedenen Merkmalen. Detaillierte Ergebnisse der SAKE. Neuchâtel: SFSO, http://www.bfs.admin.ch/bfs/ portal/de/index/themen/03/03/blank/data/02.html (08.02.2016).

Sørensen, Aage B. 1983. Processes of Allocation to Open and Closed Positions in Social Structure. Zeitschrift für Soziologie 12(3): 203-224.

Sørensen, Aage B. 2000. Employment Relations and Class Structure. Pp. 16-42 in Renewing Class Analysis, edited by Rosemary Crompton, Fiona Devine, Mike Savage, and John C. Scott. Oxford: Blackwell Publisher.

Stalder, Barbara. 2011. Das intellektuelle Anforderungsniveau beruflicher Grundbildungen in der Schweiz. Ratings der Jahre 1999-2005. Basel: TREE.

Stalder, Barbara E., and Christof Nägele. 2011. Vocational Education and Training in Switzerland: Organisation, Development and Challenges for the Future. Pp. 18-39 in Transitionen im Jugendalter. Ergebnisse der Schweizer Längsschnittstudie TREE, edited by Manfred M. Bergman, Sandra Hupka-Brunner, Anita Keller, Thomas Meyer, and Barbara E. Stalder. Zurich: Seismo.

Stata. 2013. Stata Treatment-Effects. Reference Manual: Potential Outcomes/Counterfactual Outcomes. Release 13. Texas: Stata Press Publication.

TREE. 2013. TREE Project Documentation 2000-2012. Basel: TREE.

Vella, Francis. 1998. Estimating Models with Sample Selection Bias: A Survey. The Journal of Human Resources 33(1): 127-169.

Wilkens, Ingrid, and Ute Leber. 2003. Partizipation an beruflicher Weiterbildung - Empirische Ergebnisse auf Basis des Sozio-Ökonomischen Panels. MittAB 3: 329-337.

\section{$9 \quad$ Appendix}

Gender $($ male $=1$ vs. female $=0)$, migrant background (modelled in terms of the language spoken at home, national language $=0$ vs. foreign language $=1$ ), country of birth (Switzerland, Liechtenstein $=1$ vs. abroad=0). Parental ISEI: Parental socio-economic status (ISEI). PISA index of social communication at home (soccom). Lower secondary education track: Educational track pursued at lower secondary level (classified as basic, extended or no formal requirements). PISA literacy score: PISA-measure on literacy skills (wleread). Level of VET: As vocational education and training in Switzerland is not a uniform level track but is instead stratified according to differing levels of demand, following Stalder (2011), upper secondary vocational education is distinguished into low-, medium- and high-level of intellectual demand of vocational education and training. Low-skill VET comprises levels 1 \& 
2, medium-skill VET comprises levels $3 \& 4$ and high-skill VET comprises levels $5 \& 6$ according to Stalder's (2011) classification. Certificates of vocational baccalaureates (BMS = "Berufsmaturität") are added as a further distinct category. Dual VET: Binary variable indicating whether the young pursued a dual VET (company and school-based) vs. a solely school-based VET. Fields of vocational education and training: divided into the broad categories of 1) printing \& design, 2) business $\&$ sales, 3) information technology 4) mechanics, electronics \& construction, 5) agriculture \& gardening, 6) medical assistance and 7) gastronomy \& hairdressing. Firm size: size of the entry firm based on the headcount (small [0-9], medium [10-99], large [100+] or missing). Self-efficacy and Persistency: binary measures on individual characteristics (measured prior to labour market entry). Self-efficacy is operationalised based on disagreement vs. agreement with the following statement from the TREE survey: I can always manage to solve difficult problems if I try hard enough. Coding is $1=$ moderately or exactly true vs. $0=$ not at all or hardly true. Persistency is operationalised based on the following statement: Even if I encounter difficulties, I persistently continue. Coding is $1=$ moderately or exactly true vs. $0=$ not at all or hardly true. The linguistic region of residence is divided into German-, French- and Italian- speaking part. Transitional unemployment: Indicator variable on unemployment experiences before finding a first job. Duration until first job: duration between graduating from VET and entering a first significant job in months, capturing early difficulties at labour market entry. Year of labour market entrance is the year when the first job is entered. As aggregate measures representing labour market entry conditions, the share of fixed-term employment present among young (18-24) employees holding a VET diploma in Switzerland (SAKE data) and the youth unemployment rate (ILO definition, SFSO 2016) at the year of graduating from VET are included.

As it is well known that tertiary education is an important predictor of the future career advancement of VET graduates, education completed at the tertiary level (after labour market entry) is further controlled for in the outcome equation when focusing on employment outcomes in 2010 . 
Table A1 Descriptive statistics

\begin{tabular}{lccc}
\hline Variables & Min. & Max. & Mean \\
\hline Binary or metric scale & & & \\
Gender (male $=1$ ) & 0 & 1 & 0.47 \\
Migrant background (yes=1) & 0 & 1 & 0.11 \\
Country of birth (CH=1) & 0 & 1 & 0.89 \\
Parental ISEI & 16 & 90 & 41.1 \\
Soccom (PISA-index) & -3.7 & 1.2 & -0.17 \\
PISA Literacy score & 27.6 & 741.9 & 496.8 \\
Dual VET (yes $=1$ ) & 0 & 1 & 0.96 \\
Unemployment (yes =1) & 0 & 1 & 0.06 \\
Duration (months) & 0 & 46 & 4.7 \\
Self-efficacy (high =1) & 0 & 1 & 0.91 \\
Persistency (high =1) & 0 & 1 & 0.89 \\
Tertiary education (yes =1) & 0 & 1 & 0.15
\end{tabular}

\section{Categories}

Lower secondary education

basic requirements

extended requirements

no formal requirements

Level of VET

low

medium

high

BMS (vocational baccalaureate)

Field of VET

printing \& design

business \& sales

information technology

mechanics, electronics \& construction

agriculture \& gardening

medical assistance 
Continuation of Table A1.

\begin{tabular}{|c|c|c|c|c|}
\hline Variables & Min. & Max. & Mean & Share in $\%$ \\
\hline \multicolumn{5}{|l|}{ Firm size (headcount) } \\
\hline small [0-9] & & & & 36 \\
\hline medium [10-99] & & & & 38 \\
\hline large [100+] & & & & 18 \\
\hline missing & & & & 8 \\
\hline \multicolumn{5}{|l|}{ Region of residence } \\
\hline German-speaking part & & & & 59 \\
\hline French-speaking part & & & & 31 \\
\hline Italian-speaking part & & & & 10 \\
\hline
\end{tabular}

Notes: This table includes unweighted sample statistics. On the sampling design, panel attrition and the construction of panel weights, see Sacchi (2011).

Source: TREE, own calculations. 